\title{
Study of abnormal haemoglobin variants using cation exchange high performance liquid chromatography (HPLC) in paediatric population of Gujarat, India.
}

\author{
Saxena S. ${ }^{1}$, Jain $\mathbf{R}^{2}$ \\ ${ }^{1}$ Dr. Shubhi Saxena, Assistant Professor, ${ }^{2}$ Dr. Richa Jain, Assistant Professor, Department of Pathology, Smt. B K Shah Medical \\ Institute and Research Centre, Vadodara, Gujarat. E6 Staff Quarters, Sumandeep Vidyapeeth, Piparia, Vadodara, Gujarat. E- \\ mail: shoobheee@gmail.com
}

Corresponding Author: Dr. Richa Jain, Assistant Professor, Smt. B K Shah Medical Institute and Research Centre, Vadodara, Gujarat, India. E-mail: dr.richa.rj@gmail.com

\begin{abstract}
Introduction: Haemoglobinopathies particularly $\beta$ thalassemia and sickle cell anemia are the most commonly encountered single gene disorders in the India; so as in Gujarat. The data pertaining to their occurrence and prevalence in the state of Gujarat are scarce and hence it was considered worthwhile to study the burden of haemoglobinopathies in Gujarat, India. The objective of current study is to find occurrence of haemoglobinopathies in paediatric population. Materials and Methods: Analysis of blood samples of 1560 cases referred to the pathology laboratory from paediatric department for the workup of anemia or other blood related disorders was done by Bio Rad D 10 Dual program HPLC instrument. Results: Of the 1560 paediatric cases, samples analyzed on Bio Rad D 10 Dual program HPLC for haemoglobinopathies, 1003 abnormal haemoglobin variants were detected in which maximum $652(65 \%)$ as sickle cell trait, $174(17.3 \%)$ as sickle cell disease, $139(13.8 \%)$ were diagnosed as $\beta$ thalassemia trait, $34(3.3 \%)$ were diagnosed as S- $\beta$ double heterozygous, $02(0.19 \%)$ as $\beta$-thalassemia major and $01(0.09 \%)$ as $\mathrm{HbE}$ trait, $01(0.09 \%)$ as $\mathrm{HbD}$ trait. Conclusion: The prevalence of haemoglobinopathies among children is more commonly seen in countries with limited resources, where priority tends to be given to tackling infant and child mortality from infections and malnutrition. This study indicates that almost all the common haemoglobinopathies are prevalent in Gujarat but sickle cell trait/anemia and $\beta$ thalassemia are very common.
\end{abstract}

Keywords: Abnormal haemoglobin variants, Gujarat, High performance liquid chromatography (HPLC), Paediatric population.

\section{Introduction}

Abnormal haemoglobin variants or haemoglobinopathies are the most common genetically inherited disorders. Every year, there are over 42 million carriers and more than 12,000 infants born with a major and clinically significant haemoglobinopathy. In India, the cumulative gene frequency of haemoglobinopathies is around $4.2 \%$ [1].

The cost of optimal management for a child with thalassemia including regular blood transfusions, chelation therapy, investigations, hospitalization and specific vaccines which is not an affordable amount by most Indian families. The result is irregular transfusions without chelation therapy, leading to complications of iron overload and early death. Patients with sickle cell disease do not require transfusions but are disabled due to severe pain as a result of vaso occlusive episodes and susceptibility to infections.

Manuscript received: $15^{\text {th }}$ October 2019

Reviewed: $26^{\text {th }}$ October 2019

Author Corrected: $1^{\text {st }}$ November 2019

Accepted for Publication: $6^{\text {th }}$ November 2019
They require antibiotic prophylaxis, specific immunizations and frequent hospitalization [2].

Haemoglobinopathies form a significant proportion of hereditary disorders in paediatric population leading to a range of myriad complication, leading to mortality in large number of afflicted patients. Published literature includes various reports on screening patient using HPLC in adults as well as paediatric population. However, there is paucity of literature on studies on exclusive paediatric population. The main objective of the study was to know the prevalence of abnormal haemoglobin variants in paediatric population in the state of Gujarat, India and to review various strategies that could be implemented for the effective control and prevention of these disorder

\section{Materials and Methods}

Setting: 1560 anemic paediatric cases (6 months to 14 years of age).

Pathology Update: Tropical Journal of Pathology \& Microbiology Available online at: www.medresearch.in 856 | P a g e 
Duration of Study: One year (September 2018 to September 2019).

Type of Study: Hopsital based retrospective study.

Sampling method: After consent from parents, $2 \mathrm{ml}$ of venous blood collected in EDTA (Ethylene diamine tetra acetic acid) coated vaccutainers from each patient were taken. The haematological profile of cases was done, which included peripheral smear examination, Complete Blood
Count including RBC indices, reticulocyte count etc. With the help of Bio Rad D 10 Dual program HPLC exact percentage of $\mathrm{HbS}, \mathrm{HbF}, \mathrm{HbA}_{2}$ and $\mathrm{HbA}$ was estimated to classify the cases.

Sample size calculation: 1560 random paediatric cases having clinical manisfestations like anemia, mild hepatosplenomegaly, weakness, repeated infections, aches and pain, fever along with family history were calculated.

\section{Inclusion criteria}

1. Patients with haemoglobin up to $11 \mathrm{gm} \%$ using machine Sysmex KX-21.

2. Paediatric age group.

3. Detection of sickle shaped cells on peripheral smear.

4. Positive sickling solubility test.

5. History of more than two blood transfusion in absence of trauma or any clinical morbidity.

Exclusion criteria: Adult age group

Data collection procedure: Paediatric patients taken from Outdoor Patients Department (OPD) and Indoor patient department (IPD).

Data analysis: done in tabular form and graphical presentation.

Ethical consideration \& permission: Signed informed consent was obtained from the parents of study subjects. The study was done according to the rules of the Ethics Committee.

Scoring system: None

Surgical procedure: None

The D 10 Dual program is based on chromatographic separation of the analytes by ion-exchange high performance liquid chromatography (HPLC). The whole blood EDTA samples are automatically diluted on the D 10 and injected into analytical cartridge. It delivers a programmed buffer gradient of increasing ionic strength to the cartridge, where the haemoglobins are separated based on their ionic interactions with the cartridge material. The separated haemoglobins then pass through the flow cell of the filter photometer, where changes in the absorbance at $415 \mathrm{~nm}$ are measured [3].

Table 1: Proportion of different haemoglobins in normal individuals and in haemoglobin disorders according to area percent: $[4]$.

\begin{tabular}{|c|c|c|c|c|}
\hline CONDITION & HbA & HbF & HbA $_{2}$ & HbS \\
\hline Normal Newborn & $25 \%$ & $75 \%$ & $<1 \%$ & 0 \\
\hline Sickle cell trait & $56-60 \%$ & 0 & $1-3 \%$ & $40 \%$ \\
\hline Sickle cell anemia & 0 & $5-10 \%$ & $1-3 \%$ & $90-95 \%$ \\
\hline$\beta$ thalassemia trait & $90-95 \%$ & $0-5 \%$ & $4-7 \%$ & 0 \\
\hline$\beta$ thalassemia major & 0 & $95-98 \%$ & $2-5 \%$ & 0 \\
\hline
\end{tabular}

Table 2: Proportion of different haemoglobins in normal individuals according to retention time in minutes:[5].

\begin{tabular}{|c|c|}
\hline Peak Name & Retention Time (minutes) \\
\hline $\mathrm{HbA}$ & $1.55-1.85$ \\
\hline $\mathrm{HbF}$ & $0.38-0.58$ \\
\hline $\mathrm{HbA}_{2}$ & $2.80-3.50$ \\
\hline $\mathrm{S}$ window & $4.02-4.30$ \\
\hline
\end{tabular}




\section{Results}

Of 1560 patients screened for haemoglobinopathies, 898 (58\%) were males and 662 (42\%) were females (Figure 1). Out of 1560 patients, 1003 (64.2\%) variant haemoglobinopathies were diagnosed (Table 3).

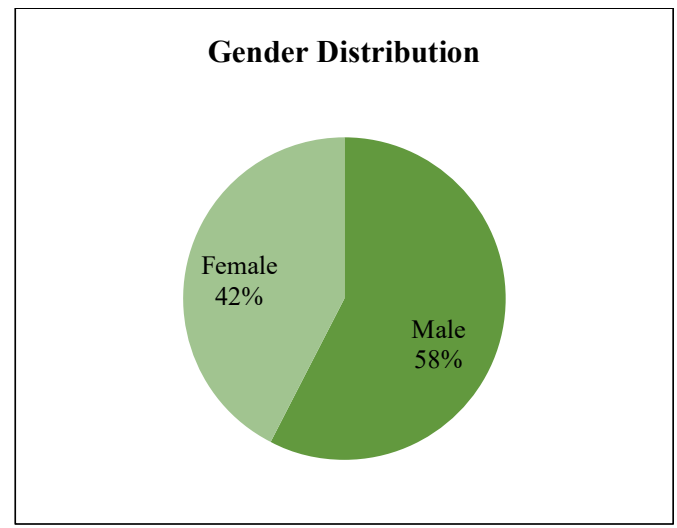

Fig-1: Gender distribution.

Presumptive identification of haemoglobin variants was made primarily by retention time (RT) windows and area percent. Of 1003 variant haemoglobinopathies detected, $543(54.1 \%)$ belonged to the 0 -5-year age group, followed by $104(10.36 \%)$ to the 6-10-year age group and $356(35.4 \%)$ to the 11-14-year age group (Table 4). Of the 1560 patients screened for haemoglobinopathies, pallor (anemia) was the most common clinical feature seen in 884 (56.6\%) patients, followed by weakness in $512(32.8 \%)$ cases, other presenting complaints include fever, hepatomegaly, splenomegaly, jaundice, growth stunting, repeated blood transfusions, failure repeated blood transfusions, failure to thrive in infants, convulsion and a positive family history.

Table-3: Distribution of abnormal haemoglobin variants in Gujarat.

\begin{tabular}{|c|c|c|}
\hline Abnormal Haemoglobin Variants & Number of patients & $\%$ \\
\hline Sickle cell trait & 652 & 65.0 \\
\hline Sickle cell disease & 174 & 17.5 \\
\hline$\beta$ thalassemia trait & 139 & 3.38 \\
\hline S- $\beta$ double heterozygous & 34 & 0.19 \\
\hline Thalassemia major & 2 & 0.09 \\
\hline HbD Trait & 1 & 0.09 \\
\hline HbE Trait & 1 & $\mathbf{1 0 0}$ \\
\hline Grand Total & $\mathbf{1 0 0 3}$ & 13.8 \\
\hline
\end{tabular}

Table 4: HPLC interpretation according to age.

\begin{tabular}{|c|c|c|c|c|c|c|c|c|c|}
\hline Age & \multicolumn{9}{|c|}{ HPLC INTERPRETATION } \\
\hline & $\begin{array}{c}\text { Beta Thal } \\
\text { Trait }\end{array}$ & $\begin{array}{c}\text { Thal } \\
\text { Major }\end{array}$ & $\begin{array}{c}\text { HbD } \\
\text { Trait }\end{array}$ & $\begin{array}{c}\text { HbE } \\
\text { Trait }\end{array}$ & HbS & $\begin{array}{c}\text { HbS } \\
\text { Trait }\end{array}$ & $\begin{array}{c}\text { S-Beta } \\
\text { Thal }\end{array}$ & $\begin{array}{c}\text { Normal } \\
\begin{array}{c}\text { Grand } \\
\text { Total }\end{array}\end{array}$ \\
\hline $\begin{array}{c}0-5 \\
\text { years }\end{array}$ & 57 & 0 & 0 & 0 & 123 & 312 & 51 & 232 & 775 \\
\hline $\begin{array}{c}6-10 \\
\text { years }\end{array}$ & 34 & 1 & 0 & 0 & 11 & 54 & 4 & 133 & 237 \\
\hline $\begin{array}{c}11-14 \\
\text { years }\end{array}$ & 118 & 0 & 1 & 1 & 46 & 177 & 13 & 192 & 548 \\
\hline $\begin{array}{c}\text { Grand } \\
\text { Total }\end{array}$ & $\mathbf{2 0 9}$ & $\mathbf{1}$ & $\mathbf{1}$ & $\mathbf{1}$ & $\mathbf{1 8 0}$ & $\mathbf{5 4 3}$ & $\mathbf{6 8}$ & $\mathbf{5 5 7}$ & $\mathbf{1 5 6 0}$ \\
\hline
\end{tabular}


Of the 1003 paediatric cases with variant haemoglobins, 759 (75.6\%) parents have history of consanguineous marriage. Majority of the cases with abnormal haemoglobin variants have microcytic hypochromic picture $758(75.5 \%)$ and $245(24.4 \%)$ have normocytic normochromic picture (Table 5).

Of the 1560 paediatric cases, 557 shows normal HPLC pattern while 1003 cases shows abnormal haemoglobin variant 652 (65 $\%)$ as sickle cell trait, 174 (17.3\%) as sickle cell disease, $139(13.8 \%)$ were diagnosed as $\beta$ thalassemia trait, $34(3.3 \%)$ were diagnosed as S- $\beta$ double heterozygous, $02(0.19 \%)$ as $\beta$-thalassemia major and $01(0.09 \%)$ as $\mathrm{HbE}$ trait, $01(0.09 \%)$ as $\mathrm{HbD}$ trait (Table 3).

Table-5: Peripheral smear findings.

\begin{tabular}{|l|c|c|}
\hline Peripheral smear findings & No of patients & $\mathbf{\%}$ \\
\hline Microcytic Hypochromic (MCHC) & 758 & 75.5 \\
\hline Normocytic Normochromic (NCNC) & 245 & 24.5 \\
\hline Grand total & $\mathbf{1 0 0 3}$ & $\mathbf{1 0 0}$ \\
\hline
\end{tabular}

\section{Discussion}

A study carried out by Christianson et al [6] estimate the prevalence of pathological haemoglobinopathies in India being 1.2/1000 live births. This suggests the annual birth of 32,400 babies with a serious Haemoglobin disorder.

These facts compel us in employing newer techniques for early detection, prevention, and treatment of hemoglobinopathies. Cation exchange HPLC is emerging as one of the best methods for screening and detection of various haemoglobinopathies with rapid, reproducible and precise results [7].

It has the advantage of quantifying $\mathrm{HbF}$ and $\mathrm{HbA}_{2}$ along with haemoglobin variant screening in single and highly reproducible system. The simplicity of the automated system with internal sample preparation, superior resolution, rapid assay time and accurate quantification of haemoglobin fractions makes this an ideal methodology for routine clinical laboratory [8].

In this study, out of 1560 patients 1003 (52.67\%) variant haemoglobinopathies cases diagnosed on Bio Rad D10 Dual program HPLC. In 2014 Mauchumisakia Pathak et al [9] studied 800 anaemic paediatric patients and found 522 $(65.25 \%)$ variant haemoglobinopathy patients. In this study, majority cases of haemoglobinopathies were found in the age group of $0-5$ year. Similar results were seen in the study by S.S Ambekar et al (2001) [10].

Out of 1560 cases of variant haemoglobinopathies detected, 898 (57.5\%) were males and $662(42.4 \%)$ were females and found comparable with Dr. Mauchumisaikia Pathak et al [9] in 2014 that is 522 cases, $268(51.34 \%)$ were males and 254 $(48.66 \%)$ were females. Endogamy and consanguinity are a common practice in the Indian subcontinent and it poses a major risk factor for the homozygous inheritance of haemoglobinopathies. Of the 1003 cases with variant haemoglobins, $759(75.6 \%)$ parents have history of consanguineous marriage. The study done by Shivashankara A.R et al [11] in 2008, J Sana et al [12] in 2008 and Colah et al [13] in 2010 reported 20\%, 24.3\% and $21 \%$ consanguinity rate in haemoglobinopathy cases. Majority of the cases in the present study belonged to tribal and low socioeconomic communities, where in the tradition of consanguineous marriages is common, thus the reason of higher percentage of consanguinity in the present study.

T. sahu et al [14] in 2003, Shah Sejal et al [15] in 2012, Dr. Mauchumisaikia Pathak et al [9] in 2014 found pallor (anemia) as most common presenting complaint in their studies which is comparable to the present study in which the most common presenting complaint was pallor in the afflicted (56.6\%) cases. A patient with sickle cell disease or trait has normochromic normocytic anemia but majority of the patients in this study had hypochromic microcytic anemia $(75.5 \%)[16]$.

This could be due to associated iron deficiency or $\alpha$ thalassaemia trait. High incidence of iron deficiency has been reported in patients with sickle cell disease from India.[17] On BIO-RAD D-10 HPLC, in thalassemia major group the average $\mathrm{HbF}$ levels were the high as compared to the other groups and it was $(88.30 \pm 11.92)$. In 2011 C.Vani et al [18] reported $\mathrm{HbF} \quad 88 \%$. Elevated $\mathrm{HbF}$ levels were encountered in double heterozygous states of $S \beta$ thal and $\mathrm{E} \beta$ thal patients. The cut off value of $\mathrm{HbA}_{2}>4.0 \%$, was used to diagnose thalassemia trait, after exclusion of the other causes of increase $\mathrm{HbA}_{2}$.

In the present study in thalassemia trait patients the average $\mathrm{HbA}_{2}$ level was found to be $(4.34 \pm 0.87)$. In 1993 G.B.Tan et al [19] reported $4.6 \% \mathrm{HbA}_{2}$ in thalassemia trait. The mean $\mathrm{HbS}$ levels in sickle cell disease patients was found 
$73.77 \pm 10.31$, in sickle cell trait $33.81 \pm 6.32$ and in $S \beta$ thalassemia patients was $42.74 \pm 16.94$.

The most common haemoglobinopathy detected was 652 $(65 \%)$ as sickle cell trait, $174(17.3 \%)$ as sickle cell disease, $139(13.8 \%)$ were diagnosed as $\beta$-thalassemia trait, 34 $(3.3 \%)$ were diagnosed as S- $\beta$ double heterozygous, 02 $(0.19 \%)$ as $\beta$-thalassemia major and $01(0.09 \%)$ as $\mathrm{HbE}$ trait, $01(0.09 \%)$ as $\mathrm{HbD}$ trait. S.S. Ambekar et al in 2001 [10] also got very low percentage of thalassemia trait $(0.5 \%)$. The reason may be because thalassemia trait patients are asymptomatic.

The frequency of sickle cell disease is $18.7 \%$ in our data. The average frequency in India is 4.3\% [20]. Timely detection of sickle cell trait can be helpful in warning patients of the possible complications and the preventive measures to be taken. Prenatal or early postnatal diagnosis of sickle cell disease helps in prompt therapy before the onset of serious complications of the disease [21].

$\mathrm{HbE}$ disease is most frequently found in Eastern and far Eastern parts of India $[22,23]$. $\mathrm{HbE}$ and $\mathrm{HbD}$ is not very common is Gujarat [24]. The incidence of $\mathrm{HbE}(0.09 \%)$ and $\mathrm{HbD}(0.09 \%)$ was very low in this study. These cases could have avoided only by doing premarital screening test of pre conceptional diagnostic tests.

The comprehensive data thus obtained can help us formulate, develop and shape infrastructure and policies for afflicted children care and provide impetus for research in the development of advanced techniques, newer drugs and diagnostic modalities. Likewise, newborn screening is primarily useful to identify infants with sickle cell disease so that early intervention with prophylactic penicillin can ameliorate complications and comprehensive care can reduce morbidity and mortality [25].

Effective prevention approaches to thalassaemia have now been demonstrated in many countries with diverse carrier screening programmes. For example, in Cyprus, Greece, the Islamic Republic of Iran and Italy, premarital screening for thalassemia is standard practice and national audit data are available; most at-risk couples are identified in time to be offered early diagnosis for the first pregnancy $[26,27]$. The majority of such couples use this service and produce healthy offspring.

Out of 1560 paediatric cases in the present study, 1003 (64.2\%) cases showed some abnormalities in hemoglobin by HPLC. Detail investigation of anemia keeping in mind the possibilities of detecting abnormal haemoglobin is very much helpful in finding out more carriers of different hemoglobinopathies. Detection of other variants becomes important due to complex interactions in cases with double heterozygous and homozygous states, which may lead to severe hematological abnormalities. CE-HPLC findings must be supplemented by hemogram, family/sibling studies, and molecular studies. Combined approach of primary and secondary prevention needs to be followed. It will prove to be cost effective by preventing the birth of child with genetic homozygous inheritance disease.

\section{Conclusion}

Thus, haemoglobinopathies exert significant burden on India, especially in the western part of the country specially Gujarat. Screening is affordable and an accessible way to detect carriers and can be offered in a range of settings in different societies: in high school, before marriage, or in antenatal clinics.

\section{What the study adds to the existing knowledge?}

Haemoglobinopathies and thalassemia are public health problem in this region of India, emphasizing the need for neonatal screening and genetic counselling programs. The HPLC based Haemoglobin testing system forms a rapid and easy tool early detection and management of various haemoglobin disorders.

Nationwide Government sponsored programme can effectively reduce the occurrence of new cases of serious haemoglobin variants as well as thalassaemia major cases and thus making it possible to direct the available resources towards the optimization of treatment of the patients who are already present. Detection of these patients with abnormal haemoglobins will help in prevention of more serious haemoglobin variant cases

\section{Author's contribution}

Dr. Shubhi Saxena: Concept, Design, Definition of intellectual content, Literature search, Manuscript preparation

Dr. Richa Jain: Experimental studies, Data acquisition, Data analysis, Statistical analysis, Manuscript preparation

Funding: No funding sources

Conflict of interest: None declared

Ethical Approval: This study was approved by the Institutional Ethics Committee

\section{Abbreviations}

HPLC: High performance liquid chromatography, CEHPLC: Cation exchange high performance liquid chromatography, HbF: Foetal haemoglobin, HbA: Adult haemoglobin, MCHC: Microcytic hypochromic, NCNC: Normocytic normochromic 


\section{References}

1. Balgir RS. The genetic burden of hemoglobinopathies with special reference to community health in India and the challenges ahead. Indian $\mathbf{J}$ Hematol Blood Trans 2002;20:2-7.

2. Kabramadhulika, Menon P. S. N. The challenge of haemoglobinopathies in India. Nat Med $\mathrm{J}$ India 1999;12(5):198-201.

3. Sood SK, Bhargava M, Shirish, Roshan C, Chandra S, Renu S. Underlying principles of D-10TM dual mode.

4. Shirish M K. Essentials of clinical pathology. $2^{\text {nd }} e d$. Faridabad: Jaypee Brothers publishers; 2018.

5. Bio Rad D10 Dual program. Customer notification: release of catridge resin lot no.70468. United states; 2018.

6. Christianson A, Howson CP, Modell B, March Dimes. Global of Report on Birth Defects: The Hidden Toll of Dying and Disabled Children. March of Dimes Birth Defects Foundation 2006.

7. Sachdev R, Dam A R, Tyagi G. Detection of Hb variants and hemoglobinopathies in Indian population using HPLC: Report of 2600 cases. Indian J Pathol Microbiol. 2010;53 (1):57-62. doi: 10.4103/0377-4929.59185.

8. Joutovsky A, Hadzi-Nesic J, Nardi MA. HPLC retention time as a diagnostic tool for hemoglobin variants and hemoglobinopathies: a study of 60000 samples in a clinical diagnostic laboratory. Clin Chem. 2004;50(10):1736-1747. doi: 10.1373/clinchem.2004.034991

9. Mauchumi SP, Monalisha SB, Dulal K. Disorders of haemoglobin variants in paediatric patients attending in a tertiary care hospital of north east India. Int J Biol Med Res. 2014;5(1):3841-3846.

10. Ambekar SS, Phadke MA, Mokashi GD, Bankar MP, Khedkar VA, Venkat V, et al. Pattern of hemoglobinopathies in western Maharashtra. Indian Pediatr. 2001;38 (5):530-534.

11. Shivashankara AR, Jailkhani R, Kini A. Hemoglobinopathies in Dharwad, North Karnataka: a hospital-based study. J Clinic Diagnos Res. 2008;2(1):593599.

12. Jalal SD, Al-Allawi NA, Faraj AH, Ahmed NH. Prevalence of haemoglobinopathies in Sulaimani-Iraq. Duhok Med J. 2008;2(1):71-79.
13. Colah R, Gorakshakar A, Phanasgaonkar S, D'Souza E, Nadkarni A, Surve R, et al. Epidemiology of betathalassaemia in Western India: mapping the frequencies and mutations in sub-regions of Maharashtra and Gujarat. Br J Haematol. 2010 Jun;149(5):739-47. doi: 10.1111/j.13652141.2010.08131.x. Epub 2010 Mar 3.

14. Sahu T, Sahani NC, Das S, Sahu SK. Sickle cell anemia in tribal children of Gajapati district in south Orissa. Ind J Comm Med. 2003;28(4):180-183.

15. Shah SJ, Chauhan SC, Rathod HK, Patel AB, Sharma VY. A profile of cases of haemoglobinopathies at a medical college. Nat J Med Res. 2012;2(2):137-140.

16. Beutler E, Lichtman MA, Coller BS, Kipps JT, Seligsohn U. Williams Hematology. 6th ed. New York: McGraw-Hill; 2001.

17. Balgir RS. The burden of haemoglobinopathies in India and the challenges ahead. Curr Sci. 2000;79(11)1536-1547.

18. Chandrashekar V, Soni M. Hemoglobin disorders in South India. ISRN Hematol. 2011;2011:748939. doi: 10.5402/2011/748939. Epub 2011 Jun 28.

19. Tan GB, Aw TC, Dunstan RA, Lee SH. Evaluation of high performance liquid chromatography for routine estimation of haemoglobins A2 and F. J Clin Pathol. 1993;46(9):852-856. doi: 10.1136/jep.46.9.852.

20. Kar BC, Satapathy RK, Kulozik AE, Kulozik M, Sirr S, Serjeant BE, et al. Sickle cell disease in Orissa State, India. Lancet. 1986;2(8517):1198-1201. doi: 10.1016/s01406736(86)92205-1

21. Philip J, Sarkar RS, Kushwaha N. Microcytic hypochromic anemia: should high performance liquid chromatography be used routinely for screening anemic and antenatal patients? Indian J Pathol Microbiol. 2013;56 (2):109-13. doi: 10.4103/0377-4929.118699.

22. Deka R. Fertility and haemoglobin genotypes: a population study in Upper Assam (India). Hum Genet. 1981;59(2):172-174. doi: 10.1007/bf00293071.

23. Balgir RS. Reproductive profile of mothers in relation to hemoglobin E genotypes. Indian J Pediatr. 1992;59 (4):449-454. doi: 10.1007/bf02751560.

24. Balgir RS. Genetic epidemiology of the three predominant abnormal hemoglobins in India. $\mathrm{J}$ Assoc Physicians India. 1996;44(1):25-28. 
25. Henthorn JS, Almeida AM, Davies SC. Neonatal screening for sickle cell disorders. $\mathrm{Br} \mathrm{J}$ Haematol. 2004;124(3):259-263. doi: 10.1046/j.1365-2141.2003. 04775.x.

26. Angastiniotis M, Kyriakidou S, Hadjiminas M. How thalassemia was controlled in Cyprus. World Health Forum. 1986;7(3):291-297.
27. Kattamis C, Metaxotou-Mavromati A, Wood WG, Nash JR, Weatherall DJ. The heterogeneity of normal $\mathrm{Hb}$ A2beta thalassaemia in Greece. $\mathrm{Br} \mathrm{J}$ Haematol. 1979;42(1):109-123. doi: 10.1111/j. 1365-2141. 1979. tb03703.x

\section{How to cite this article?}

Saxena S., Jain R, Study of abnormal haemoglobin variants using cation exchange high performance liquid chromatography (HPLC) in paediatric population of Gujarat, India. Trop J Path Micro 2019;5(11): 856-862.doi:10.17511/jopm. 2019.i11.04 